DEPARTMENT OF THE INTERIOR

UNITED STATES GEOLOGICAL SURVEY

PREPARED IN COOPERATION WITH

THE COMMONWEALTH OF KENTUCKY, UNIVERSITY OF KENTUCKY KENTUCKY GEOLOGICAL SURVEY

WALLACE W. HAGAN, DIRECTOR AND STATE, GEOLOGIST

\title{
MAP SHOWING BEDROCK TOPOGRAPHY AND SUBCROP OF SELECTED BEDS BENEATH ALLUVIAL DEPOSITS OF THE GROVE CENTER QUADRANGLE AND PART OF THE SHAWNEETOWN QUADRANGLE, KENTUCKY-ILLINOIS \\ By \\ Avery E. Smith
}

\section{MISCELLANEOUS GEOLOGIC INVESTIGATIONS MAP I-954}

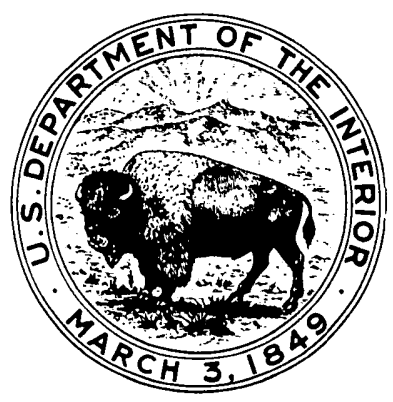

